\title{
GENDER INEQUALITIES IN ITALIAN ACADEMIA. WHAT FUTURE FOR FEMALE ACADEMICS?
}

\author{
DESIGUALDADES DE GÉNERO EN LA ACADEMIA ITALIANA. \\ ¿CUÁL ES EL FUTURO PARA LAS MUJERES ACADÉMICAS?
}

\author{
Emanuela SALA \\ University of Milano Bicocca (Italy) \\ emanuela.sala@unimib.it \\ orcid.org/0000-0003-2988-579X \\ Roberta BOSISIO \\ University of Turin (Italy) \\ roberta.bosisio@unito.it \\ orcid.org/0000-0002-1091-0038
}

\begin{abstract}
In the last 20 years, the Italian Ministry of Education, University and Research (MIUR) has enacted two major reforms and passed a number of parliamentary acts that have radically changed the Italian academic system, e.g., the role of the permanent researcher was abolished and different types of fixed-term researchers were introduced. So far, very little is known on the effects of these reforms on men and women's career progressions. Using a unique dataset that includes information on the whole Italian academic staff, this paper aims to provide an overview of the changes that the reforms introduced in the academic system and compare male and female scholars' conditions within the university. The focus of the paper is on the young cohorts of academics who work as researchers. The main finding is that, in a context in which the selection and recruitment processes are not exclusively based on merit, the «gender neutral» MIUR reforms are contributing to the reproduction of the female disadvantage.
\end{abstract}

Keywords: women in science, gender inequalities, early career researchers, university reforms, women's career. 


\section{Resumen}

En las últimas dos décadas, el Ministerio italiano de Educación, Universidad e Investigación (MIUR) promulgó dos reformas y aprobó un gran número de procedimientos parlamentarios que cambiaron radicalmente el sistema académico italiano, por ejemplo, el papel del investigador permanente fue suprimido y fueron introducidos varios tipos de investigadores a plazo fijo. Hasta aquí, muy poco es conocido sobre los efectos de estas reformas en las progresiones de carrera de hombres y mujeres. A través de un único conjunto de datos, lo cual incluye informaciones sobre el personal académico interno de Italia, éste artículo tiene como objetivo proporcionar un resumen de los cambios en el sistema académico introducidos por las reformas y una comparación entre las diferentes condiciones de los académicos hombres y mujeres en la Universidad. El foco de esta investigación está en las cohortes más jóvenes de académicos que trabajan como investigadores. El principal hallazgo es que, en un contexto donde los procesos de selección y reclutamiento no están basados exclusivamente en el mérito, las reformas de género neutral del MIUR están contribuyendo a la reproducción de la desventaja femenina.

Palabras clave: mujeres en la ciencia, desigualdades de género, jóvenes académicos, reformas universitarias, carrera de mujeres 


\section{INTRODUCTION ${ }^{1}$}

Academia should be the «reign of meritocracy». In theory, selection and promotion processes should only be based on meritocratic criteria, i.e., the evaluation of the academic's productivity and teaching ability. However, reality seems to be quite different. In Italy, male and female career progressions seem to be governed by social mechanisms that have little to do with individual merit and somehow end up favouring men. In a previous work, we have drawn a quantitative picture of men and women's conditions in Italian universities, focusing on the ranks of full and associate professor and university researcher (Sala and Bosisio 2007). Since 2005, the Italian Ministry of Education, University and Research (MIUR) has enacted major reforms that have radically changed the Italian academic system, modifying the associate and full professors' promotion processes, abolishing the role of permanent researcher, and introducing different types of fixed-term researchers (i.e. with a dependent employment relationship with a duration of three years, eventually renewable). The overall aim of this work is to analyse men and women's conditions in the Italian academia, focusing, in particular, on the tenure and non-tenure researchers. After providing an overview of the legislative framework and discussing the MIUR reforms, we look at men and women's condition within the university (i. e., the horizontal and vertical segregation) and evaluate the impact of the recent reforms on their career paths.

\section{GENDER INEQUALITIES IN ENTERING THE ACADEMIC CAREER. STILL AN UNDERRESEARCHERD TOPIC}

We know very little about men and women's conditions within Italian universities. The few studies on this topic are quite dated. A publication by the Italian National Statistical Institute (ISTAT, 2001) has provided a detailed overview of male and female career patterns, documenting that the men's careers are faster than women's and the chances of making a career in academia are dependent

1. Although this paper is a joint work, Emanuela Sala wrote section 1, 2, 4, 5 and 6 and Roberta Bosisio section 3. 
on the disciplinary field in which academics work. In addition, the research has also shown the gendered nature of the recruitment processes, e. g., women are more likely to be hired through public competitions based on merit. Carabelli et al. (1999), investigating the factors driving male and female economists' differential professional outcomes, claim that gender differences in career paths cannot be traced to differences in men and women's work commitment. These differences may rather be brought back to the characteristics of the recruitment and promotion processes that are based on the principle of the so-called oldboys' network (mainly constituted by men). Bianco (2002) assessed the impact of the 1998 university reform on men and women's chances of professional growth. She concludes that the reform did not have any impact on the disparities in men and women's career progressions, although there was an increase in the number of women promoted to the role of associate professor. The role of family commitments on female academics' career is still unclear and appears to be more complex than expected. Facchini and Schmitz (1997) showed that having a family hampers women's career in academia whereas Rosselli (1999) found no differences in career progressions when comparing childless women to female academics with two or more children.

Despite of the shortage of scientific publications, issues concerning men and women's careers in academia are often discussed in the so-called "grey literature». Lavoce.info published a number of short reports that assessed the impact of the new promotion processes on male and female academics (see the next section). De Paola, Ponzo and Scoppa have shown that although men are more likely than women to apply for the national accreditation to associate professorships (2014a), there are no gender differences in the likelihood of being accredited (2014b). However, once accredited, men are more likely than their female colleagues to be recruited as associate or full professor (De Paola, Ponzo and Scoppa 2015). Another interesting contribution is by Bagues, Sylos Labini and Zinovyeva (2014). The authors have shown that the presence of women in the evaluating panel for the national accreditation has a negative impact on women's likelihood to be accredited to associate or full professor. The blog Return on Academic Research (ROARS) is also active in debating issues concerning the Italian academic system. In his contribution, Baccini (2014) found further evidence that supports De Paola, Ponzo and Scoppa's results (2014b); there are no gender differences in the likelihood of being accredited as associate or full professor. 
To the best of our knowledge, there are no scientific publications that look at the condition of young male and female researchers in Italian academia ${ }^{2}$. When considering the major Italian sociological journals (i. e., Polis, Rassegna Italiana di Sociologia and Quaderni di Sociologia), we found no papers published on these topics, at least since 2010. The Italian journal About Gender, which publishes contributions on gender issues, has not published any papers on young male and female academics' conditions either. There are research reports on gender inequalities in Italian universities. Although Frattini and Rossi's work focuses on women's career progressions, the authors do not analyse young male and female researchers' career paths (2012). The Italian Economic Society, which is particularly active in monitoring gender inequalities in the economic profession, did perform an analysis on male and female Ph.Ds' career progressions (Corsi 2014 and 2016), but it did not focus on young tenure and non-tenure researchers. It is also worth mentioning that the Italian Association of Ph.D students and Ph.D holders (ADI) has published a number of reports in which they look at young researchers' work conditions within Italian academia. However, they do not usually tackle gender issues in their reports. The situation may change in the near future: the GARCIA project (Gendering the Academy and Research: combating Career Instability and Asymmetries) has recently ended and some interesting papers may be published soon. Our work rests within this research context. Given the lack of knowledge in this area, it is meant to contribute to fill in this gap.

\section{THE RESEARCHER IN ITALIAN UNIVERSITIES: CREATION AND EVOLUTION OF THE ROLE}

Teaching and research staff in the Italian university system currently consists of tenured professors and researchers hired under a fixed-term or permanent employment contract, and temporary/occasional research and teaching staff whom the university engages under a range of contractual arrangements with no proper guarantees. It is important to notice that the recruitment procedures for tenured academic teaching and research staff are established at the national level.

Since the '80s, tenured staff has consisted of full professors at the top of the hierarchy, followed by associate professors and researchers (Presidential Decree 382/80). Pursuant to the legislative framework in force at that time, access to full and associate professorships was gained through competitive examinations which, after determining whether the candidates' academic qualifications were

2. When talking about young researchers we refer to early career researchers.

Feminismo/s 29, junio 2017, pp. 347-368 
appropriate, also entailed a teaching demonstration and a discussion of their publications.

Before Law 230/2005 (the so-called Moratti reform) was promulgated, researchers - like associate professors and full professors - were employed under an open-ended contract, receiving tenure after successfully passing a review held three years after their initial appointment. ${ }^{3}$ The researcher role was introduced for those who were involved in specific research activities although, in practice, it represented the lowest rank of the academic teaching staff (David 1994).

Law 230/2005 established September 30, 2013 as the final deadline for filling vacant researcher positions using the procedures contemplated by Law $210 / 1998$, and introduced the role of fixed-term researcher. This law was later affected by the most recent academic reform, Law 240/2010 (the so-called Gelmini reform), which made further changes to the status of university researchers.

Consequently, the term researcher covers a disparate population whose prerogatives are not always clear. Indeed, this role's introduction in 1980 (Presidential Decree 382/80) has been followed, as we have mentioned, by a succession of legislative measures, which, on the one hand, modified the recruitment procedures and duties of permanent researchers, and on the other hand introduced three types of fixed-term researcher contracts.

Currently, several types of researcher thus coexist in the Italian university system: permanent researchers (pursuant to Presidential Decree 382/80 as amended by Law 210/1998); fixed-term researchers established by the Law 230/2005, and Type A and Type B fixed-term researchers established by the Law 240/2010.

We will now look at the prerogatives, rights and duties associated with these positions (see Table 1).

\subsection{Permanent researchers}

Under the terms of Presidential Decree 382/1980, competitive examinations for posts as researchers were announced at the local level. The examining board, consisting of a full professor named by the Faculty Board (the internal member) together with a full professor and an associate professor drawn from a group designated by the National University Council, assessed candidates on the basis of two written and one oral test designed to gauge the candidates' aptitude for

3. Presidential Decree 382/1980 and Law 210/1998 (the Berlinguer Reform) governed their recruitment and legal status. 
research as well as their scientific and teaching qualifications. The National University Council defined the tests, assessment criteria and scoring system.

With Law 210/1998, the composition of the board of examiners for candidate researchers was changed to include one full professor, one associate professor and one researcher. The faculty board retains the right to name an internal member (either a full or an associate professor), while the other two members are elected by their colleagues of equal rank.

Assessment has also changed over time: assessment consisting of a review of academic qualifications and publications, plus written and oral tests ${ }^{4}$ has given way to assessment «based on the candidates' academic qualifications as illustrated and discussed before the board, and their publications, including doctoral dissertations, using internationally recognized parameters». ${ }^{5}$

With regards to researchers' duties, while it was originally planned that they would be chiefly engaged in research, their teaching responsibilities have come to occupy an increasingly significant proportion of their time over the years. Whereas researchers were initially given only supplementary teaching and tutoring assignments, since 2010 they have been «assigned courses and modules in the regular curriculum, with their consent and with no change in their legal and contractual status and salary». ${ }^{6}$ The gradual reduction in teaching staff ${ }^{7}$ and the importance of teaching to career advancement, moreover, have meant that researchers' acceptance of assigned courses and modules can be taken for granted.

Advancement to associate professor is generally contingent to participation in competitive examinations conducted according to the procedures laid down in Law 210/1998 and Presidential Decree 117/2000, and to the regulations adopted by each university.

However, the Gelmini reform states that until December 31 of the sixth year following its entry into force, universities can promote permanent researchers on their faculty who have received national accreditation to associate professorships. ${ }^{8}$

4. Presidential Decree $382 / 80$ as amended by Law 210/1998.

5. Law $1 / 2009$.

6. «Each university, to the extent permitted by its budget and on the basis of criteria and procedures set forth in its own regulations, shall determine the additional compensation paid to researchers to whom modules or courses in the regular curriculum are assigned with their consent» (Article 6, Law 240/2010).

7. According to the 2016 Report by the Fondazione Res (Viesti, 2016), the number of researchers and full or associate professors with teaching duties in Italian universities dropped by over 7,800 between 2008 and 2015 .

8. In accordance with the procedure contemplated by clause 5, Article 24 of Law 240/2010.

Feminismo/s 29, junio 2017, pp. 347-368 


\subsection{Fixed-term researchers ('Moratti contracts' as per Law 230/2005)}

The Moratti reform, in addition to phasing out open-ended contracts for researchers, introduced fixed-term researcher positions for the first time. Article 14 of the law requires that for the research and supplementary teaching activities hitherto included among the duties of permanent researchers, universities must establish «dependent employment relationships by entering into fixed-term contracts» with a maximum duration of three years and renewable for a total of up to six years. For this purpose, comparative assessment procedures governed by each university's regulations shall be used to recruit individuals with «high scientific qualifications»: candidates «having a $\mathrm{PhD}$ or postgraduate specialization, or who have taught a university course under the terms of a contract entered into pursuant to the provisions applying at the time this law comes into force will be given preferential consideration».

Remuneration for this type of fixed-term researcher is $120 \%$ of the starting salary of permanent researchers. ${ }^{9}$

\subsection{Type A and Type B fixed-term researchers ('Junior Gelmini' and 'Senior Gelmini' contracts as per Law 240/2010)}

The fixed-term researchers established by the Moratti reform - like that of permanent researchers - is being phased out, as the Gelmini reform repealed Article 1 of Law L. 230/2005, bringing further changes for researchers' recruitment and status. Like the previous law, the Gelmini reform also requires that research, teaching, supplementary teaching and student assistance be carried out by individuals selected by means of public assessment procedures and employed under fixed-term contracts. ${ }^{10}$

Two types of fixed-term contract are contemplated. The first, or Type A, are three year contracts that can be extended for a further two years $(3+2)$, at a salary equal to that of permanent researchers.

The second, or Type B contract, is also for three years but cannot be renewed. Candidates who can apply for these positions include those who have previously had: a) a Type B fixed-term contract; b) a research grant for at least three years (not necessarily consecutive) $;{ }^{11}$ or c) postdoctoral fellowships. ${ }^{12}$

9. Article 2, Interministerial Decree 94/2009.

10. Article 24 of Law 240/2010 established criteria and procedures for selecting candidates. It should be emphasized that these criteria include experience in teaching and in coordinating national and international research groups.

11. Article 51 of Law 449/1997.

12. Article 4, Law 398/1989. 


\begin{tabular}{|c|c|c|c|c|}
\hline 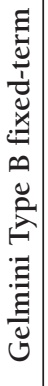 & 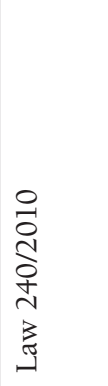 & 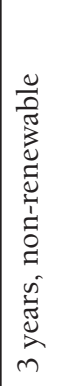 & 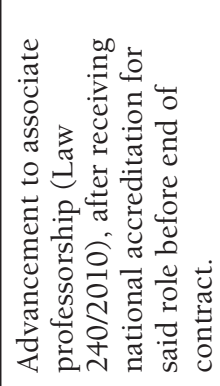 & 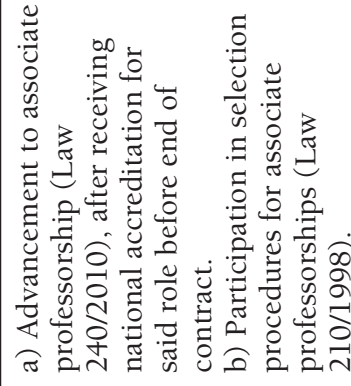 \\
\hline 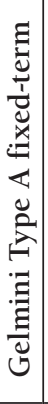 & 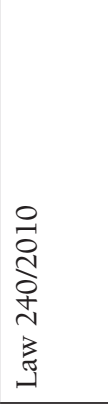 & 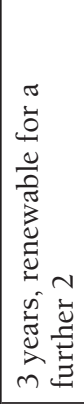 & 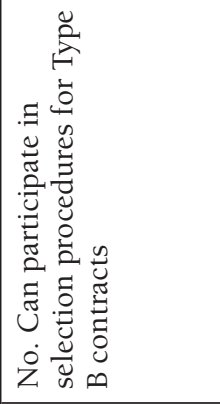 & 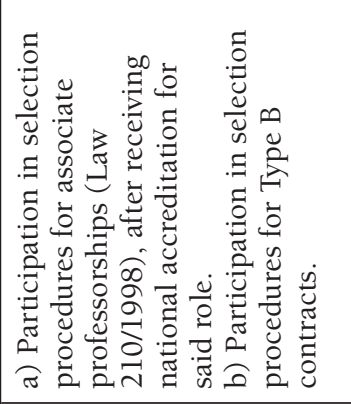 \\
\hline 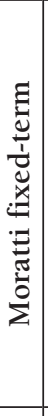 & 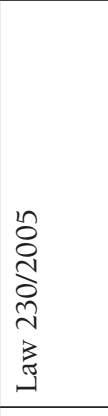 & 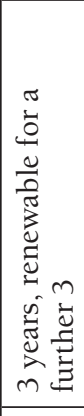 & 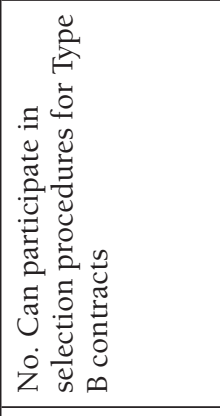 & 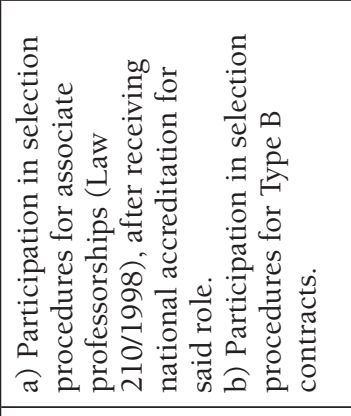 \\
\hline 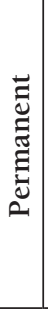 & 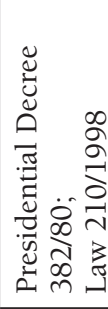 & 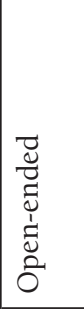 & 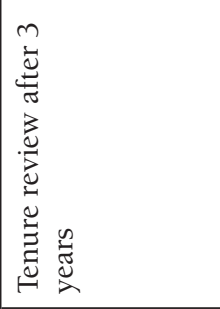 & 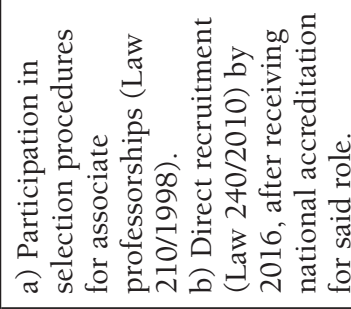 \\
\hline 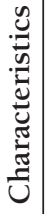 & 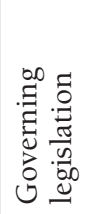 & 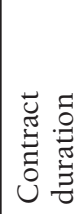 & 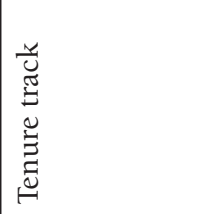 & 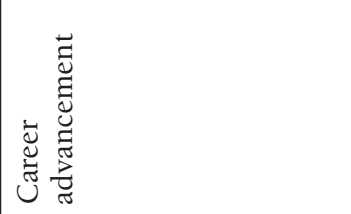 \\
\hline
\end{tabular}

Feminismo/s 29, junio 2017, pp. 347-368 
Calls for this type of contract are open to those who have had a Type A contract or held an equivalent position for at least three years, even if they do not have a PhD (ROARS Editorial Board, 09.09.2016).

If the researcher has received national accreditation for employment as an associate professor before the end of the third year of the contract, the university will assess his or her curriculum vitae «for purposes of recruitment for associate professorships» at the time the Type B contract expires. ${ }^{13}$

For researchers with Type B contracts, compensation is equal to that of permanent researchers, and can be increased by a maximum of $30 \%$.

In summery, in Italian universities there are currently four types of researchers: permanent researchers, Moratti fixed-term researchers (who are being phased out), and type A and B Gelmini fixed-term researchers.

The major difference amongst the three types of fixed-term contracts lies in the career opportunities associated to these roles; the Moratti and Gelmini Type A researchers do not offer any chances of university career progression, whereas the Gelmini Type B researcher is an «entry ticket» into the academic profession. Once their contract expires, most of the Moratti and Gelmini Type A researchers will need to apply for another researcher position whereas most of the Gelmini Type B researcher will become associate professors.

In the remaining part of this paper, we use the terms tenure track researcher and non-tenure researcher when referring to Gelmini Type B and A researcher, respectively.

\section{DATA}

We use administrative data from the databases University Search (Cerca Università) and Temporary Teaching Staff and Administrative Staff (Banca Dati del Personale Docente a Contratto e Tecnico Amministrativo) run by the Italian Ministry of Education, University and Research (MIUR). These databases collect information on the university staff that work in all public and private universities in Italy; the data refer to 31 of December of each year. The first one collects the following information on university teachers: role, tenure, sex, disciplinary field, faculty or department, and university. The data are available since 2000. The second one collects information on research fellows' sex and university affiliation and is available since 2003. The two databases are available at http://cercauniversita.cineca.it/ and http://statistica.miur.it/, respectively.

13. Article 24, clause 5, Law 240/2010. For a critical analysis of this procedure, see: Bellavista A., Il reclutamento dei professori e dei ricercatori universitari dopo la legge «Gelmini», http://www.roars.it/online/, 21-10-2012 


\section{RESULTS}

\subsection{Women in academia: Still a minority and still disadvantaged}

Table 2 shows the composition by sex of the Italian academic staff in 2016. As the data in column «Total» shows, the academic body is rather equally distributed among the different ranks; the full professors and the associate professors constitute $23.7 \%$ and $36.8 \%$ of the academic staff, respectively, whereas the researchers are $29.9 \%$. It is worth noting that the majority of the researchers have permanent positions.

There are strong differences in men and women's presence in academia. First, men's distribution amongst the different academic ranks is more equal than women's; the former is cone-shaped, the latter is markedly pyramid-shaped. Second, female academics are still in a minority; women are only $37.2 \%$ of the whole university staff. The feminisation rate, i.e., the percentage of women in a given category, is not constant but varies amongst the different ranks, showing a linear and negative trend. Indeed, women are $22.1 \%$ of the full professors, $37.1 \%$ of the associate professors and $47.9 \%$ of the researchers with a permanent position. Despite of this, women's presence within Italian academia has very slowly but constantly increased over time; the feminization rate has increased from 30.0 to 37.2 in 16 years (see also Section 4.3). The gender differences in the Italian university are due to a combination of factors: gender discrimination the delayed entry of women in the university career, the cultural and structural obstacles that women face when entering a world that is mainly dominated by men, and the lack of specific policy interventions to support women's careers (Bianco, 1997).

Researchers with temporary positions are currently $9.6 \%$ of the academic staff; female scholars seem to be overrepresented in this rank, being $10.7 \%$ of the university researchers and teachers compared to $9 \%$ of men. Interestingly, even within the younger cohorts of academics, we find the same pattern of gender differences that we have described in the previous paragraphs. Women are a minority in the three temporary positions that we consider, although since 2010 there have been no gender differences in the composition of the research fellow rank. In addition, when female academics manage to get a temporary position, they are more likely than men to be in the non-tenure research track. In the long run, this mechanism will have a detrimental impact on the gender composition of the academic staff. As already mentioned, non-tenure researchers have no future in Italian universities; when their contract expires, they will need to find another job (within or outside academia). When the tenure researchers' contract expires, they are likely to be promoted to associate professors. 
To sum up, Italian academia is still characterised by a strong degree of vertical segregation. This situation is also mirrored in the younger cohort of academics.

Table 2. Academic staff in Italian universities (2016). Column percentages and feminilization rate

\begin{tabular}{|c|c|c|c|c|c|}
\hline \multirow[t]{2}{*}{ Academic rank } & \multicolumn{2}{|c|}{ Sex } & \multirow[t]{2}{*}{ Total } & \multirow{2}{*}{$\begin{array}{l}\text { Feminilization } \\
\text { rate }\end{array}$} & \multirow{2}{*}{$\begin{array}{c}\text { Feminilization } \\
\text { rate } 2000\end{array}$} \\
\hline & Men & Women & & & \\
\hline \multicolumn{6}{|l|}{ Panel A } \\
\hline \multicolumn{6}{|l|}{ Permanent positions } \\
\hline Full professor & 29.4 & 14.1 & 23.7 & 22.1 & 15,4 \\
\hline Associate professor & 36.8 & 36.7 & 36.8 & 37.1 & 27,7 \\
\hline Researcher & 24.8 & 38.5 & 29.9 & 47.9 & 41,7 \\
\hline \multicolumn{6}{|l|}{ Temporary positions } \\
\hline Tenure researcher & 3.2 & 3.5 & 3.3 & 39.8 & $\mathrm{n} / \mathrm{a}$ \\
\hline Non-tenure researcher & 5.5 & 6.7 & 5.9 & 42.1 & $\mathrm{n} / \mathrm{a}$ \\
\hline Moratti researcher & 0.3 & 0.5 & 0.4 & 48.5 & $\mathrm{n} / \mathrm{a}$ \\
\hline $\mathrm{N}$ & 34,009 & 20,118 & 54,127 & 37.2 & 30.0 \\
\hline \multicolumn{6}{|l|}{ Panel B } \\
\hline Research fellow & 10201 & 10467 & 20668 & 50.6 & 52.6 \\
\hline
\end{tabular}

Source: University Search Database and Temporary Teaching Staff and Administrative Staff. Retrieval date: 8/12/2016.

Note: Data on the number of research fellows refer to 2015 and 2003. Retrival date: 06/02/2017.

\subsection{Women in academia: Disciplinary fields can make the difference}

As Table 3 shows, there is wide variation in the female presence amongst the different disciplinary fields. Indeed, the feminization rate varies between $16.5 \%$ for industrial engineering (9) and 54.3\% for the humanities (10). However, when analysing these data more carefully, we can clearly identify three distinct clusters of disciplines: a predominantly male cluster, where women are less than 30\% (physics, geology and engineering), a cluster with an intermediate female presence (e. g., medicines, law, economics, etc.), and a cluster with a relevant female presence, where women are at least 45\% (e.g. the humanities). 
For all disciplines, the characteristics of these clusters are particularly marked when considering the full professors and become less distinct when focusing on the associate professors and, especially, the researchers who hold permanent positions. Overall, the pattern we have just described is also reflected in the gender composition of the researchers with temporary position. For example, the feminization rate of the non-tenure researchers varies between 19\% for industrial engineering and information and communication technology (9) and $52.6 \%$ of the humanities (10).

Analysing more in detail the data on the temporary staff, two main findings stand out. First, for most of the disciplines, the percentage of female tenure track researchers is higher than the total feminization rate of a given discipline. For example, female tenure track researchers in the medical field (6) are $41.1 \%$, compared to $32.3 \%$ of all female medics. Physics (2), chemistry (3), biology (5), humanities (11), political and social sciences (14) are exceptions to this trend. Although the increase in the presence of women academics is good news, we would be careful in concluding that Italian universities will be more gender balanced in the future; indeed, it is worth recalling that women are the majority of the research fellows. Unfortunately, we have no data on the gender composition of this group of academics by disciplinary fields and, therefore, we cannot perform a more in-depth analysis.

Second, for most of the disciplinary fields there are differences in the presence of women amongst the three temporary position ranks. When comparing the feminization rate of the tenure and non-tenure researchers, we find that women are underrepresented in nine disciplinary fields. The differentials in the presence of women between the two ranks are particularly marked for chemistry (3), sociology and political science (14) where the differences in the two feminization rates are 16.9 and 20.8 percentage points, respectively. Interestingly, there seems to be an association between the gender differences in the tenure and non-tenure track researchers and the presence of women in a given discipline; the disciplines with a high presence of women (i. e., chemistry, sociology and political science) are also the disciplines with the highest differentials. On the contrary, the disciplines with the lowest feminization rates are amongst the disciplines with the lowest differences in the presence of women between tenure and non-tenure researchers, i. e., physics (2) and industrial engineering (9). As the non-tenure researchers have very little chances of career progression within the university, we conclude that, for some disciplines, the marked differentials in the feminization rate of tenure and non-tenure researchers will accentuate the existing gender differences. Overall, Italian academia is still characterised by a high degree of horizontal segregation. 


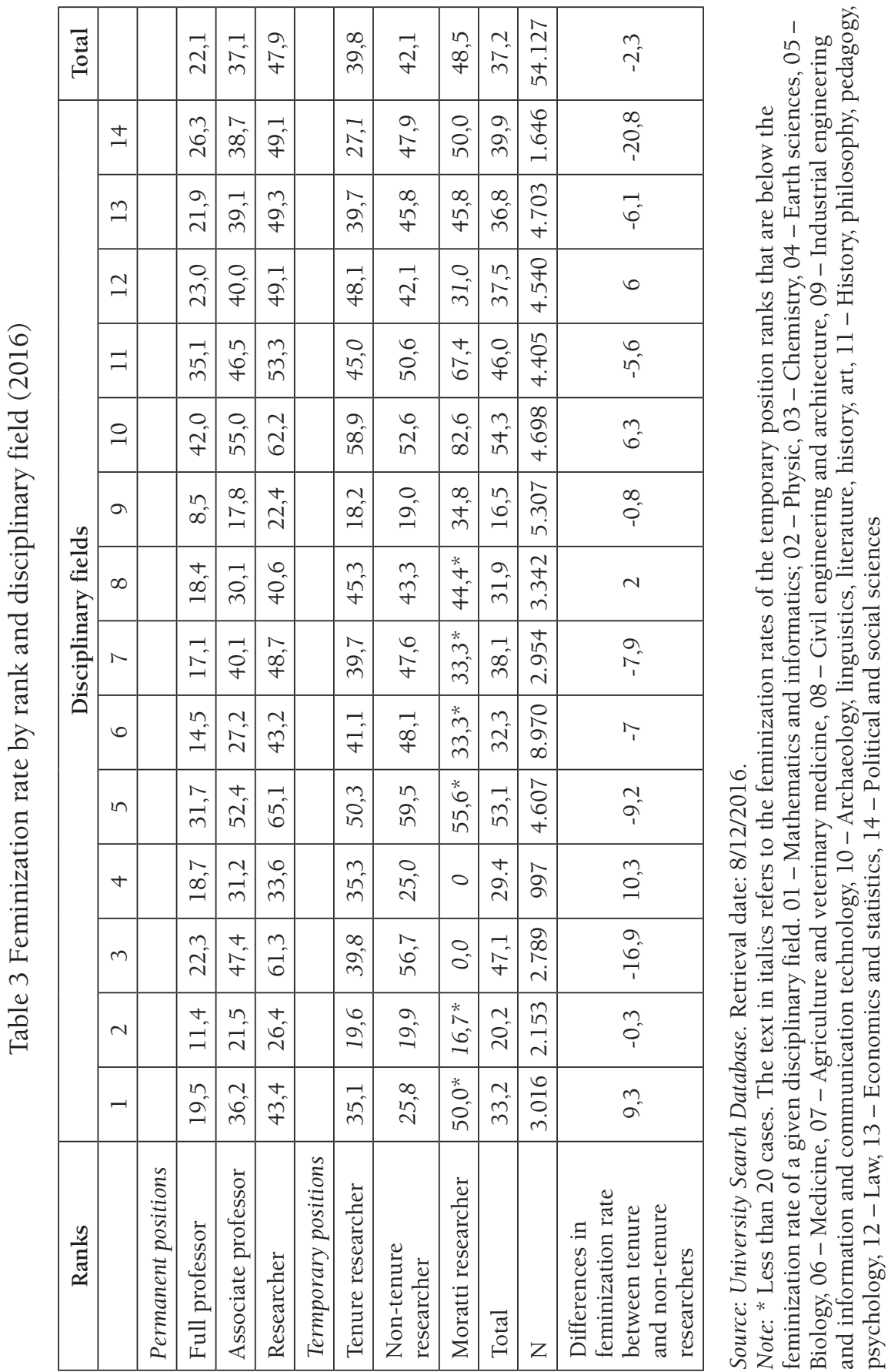




\subsection{Women in academia: changes over time}

We aim to assess the impact of the so-called Moratti and Gelmini reforms on female academics' career opportunities and, in particular, on young researchers' ones. We therefore limit our analysis to the 2010-2016 data.

The data in Graph 1 and Table 4 show a constant reduction in the size of the university staff; the number of professors and researchers shrunk from 58,884 to 54,127 units between 2010 and 2016 (see also Pavolini and Viesti 2016). This reduction has mainly concerned the ranks of the full professors and the permanent researchers. The factors that are driving these changes are different. The reduction in the number of the full professors can be brought back to structural reasons, i. e., the retirement of (mainly male) professors as well as the lack of economic incentives to hire/promote new full professors. The reduction in the size of the permanent researchers is a direct consequence of the university reform that abolished this rank. The case of the associate professor is particularly interesting; after an initial decrease, the size of the associate professor rank started to increase sharply in 2014. This increase is due to a special recruitment plan financed by the MIUR, the so-called Piano Straordinario per il reclutamento degli Associati. As one may expect, the increase in the size of the associate professors corresponds to the decrease in the number of permanent researchers.

Despite the changes that occurred between 2010 and 2016, women's condition within the Italian university has not undergone major changes. However, the analysis of the feminization rates shown in Table 4 indicates a slow but constant increase in the presence of women within the ranks of the full and associate professors and the permanent researchers. For example, between 2010 and 2016, the percentage of female full professors increased by 2 percentage points, from $20.1 \%$ to $22.1 \%$. Similar to what we stated previously, we would be careful in concluding that Italian academia is turning into a «land of equal opportunities». Rather, we would speculate that a number of structural factors has contributed to the increase in feminization rates. For the female full professors, the increase is due to the retirement of the mainly male professors (recall that there have been very few new recruitments of full professors recently). For the associate professors and the permanent researchers the reasons that lead to the increase in feminization rates can be brought back to the aforementioned special recruitment plan of the associate professors. Although men, more than women, benefitted from these new career opportunities, some women were also successfully promoted/hired as associate professors. This has led to an increase in the percentage of female associate professors but at the same time, an increase in the proportion of female permanent researchers. 


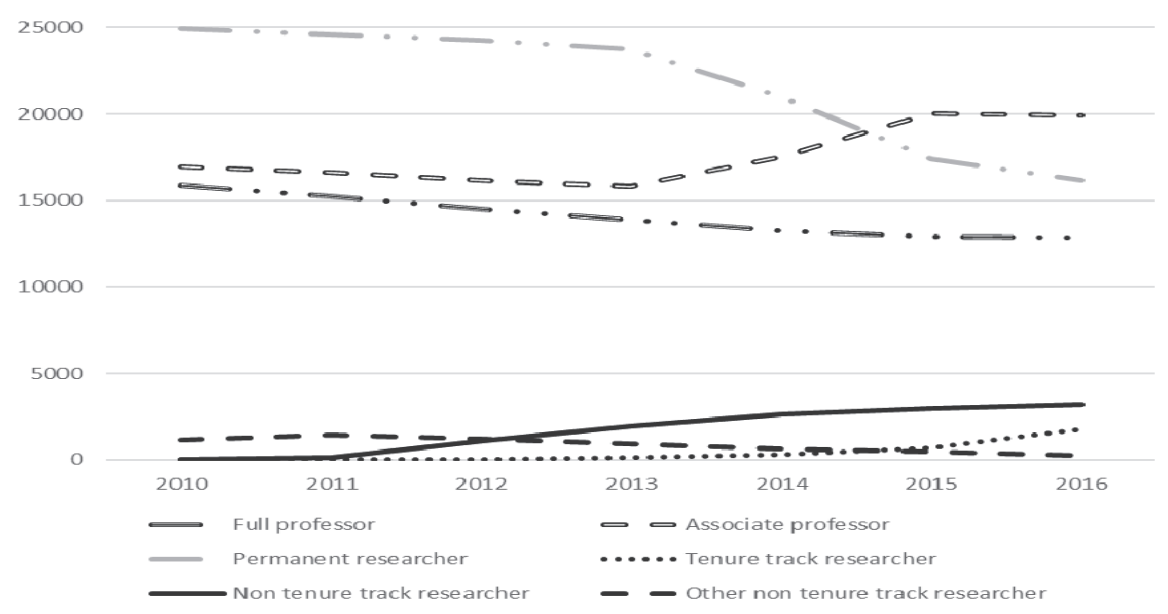

Figure 1. Changes in the composition of the university staff (2010-2016)

As consequence of the introduction of the Gelmini reform, the number of researchers employed with fixed-term contacts has been constantly increasing over time. This increase is due to the increase in the number of the tenure and, especially, non-tenure researchers. As hiring tenure researchers is more expensive than recruiting non-tenure ones, universities prefer to recruit young academics without tenure. This is also apparent when looking at the gap between the number of tenure and non-tenure researchers, shown in the graph and in Table 3. In 2016, the MIUR financed a special recruitment plan, the so-called Piano straordinario per il reclutamento di ricercatori di tipo $B$, that aimed to hire new tenure researchers. This plan was successful in reducing this gap, which, however, still persists at the end of 2016.

When focusing on young female scholars' career opportunities, we limit our analysis to the years 2013-2016. The analysis of the feminization rates of the three ranks shows a clear pattern, i. e., women are underrepresented within the tenure researchers and overrepresented within the non-tenure track researchers, especially within the «Moratti» researcher. For example, in 2015 the percentages of female academics within these three ranks were $38.1 \%, 43.3 \%$ and $46.6 \%$, respectively. It is worth noticing that the presence of women within the «Moratti» researchers is constantly increasing over time; between 2010 and 2016, the femilization rate has increased from $40.2 \%$ to $48.5 \%$. Similar to what we stated previously, we speculate that this can hardly be seen as an improvement in women's chances to make an academic career. We rather believe that most of the male researchers originally employed with 


\begin{tabular}{|c|c|c|c|c|c|c|c|c|c|c|c|c|c|}
\hline \multirow{14}{*}{ 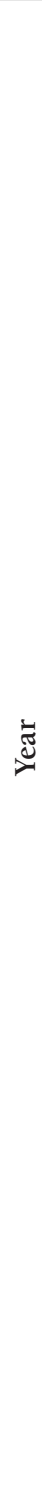 } & \multirow{2}{*}{ 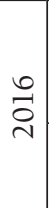 } & 点 & & & $\begin{array}{l}\vec{n} \\
\infty \\
\tilde{c}\end{array}$ & $\begin{array}{l}\tilde{N} \\
\tilde{\sigma} \\
\sigma\end{array}$ & $\begin{array}{l}\hat{0} \\
6 \\
-1\end{array}$ & $\begin{array}{l}\infty \\
\infty \\
-1 \\
-1\end{array}$ & $\begin{array}{l}0 \\
\stackrel{1}{0} \\
\text { m }\end{array}$ & તิ & 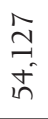 & & $\stackrel{\pi}{a}$ \\
\hline & & 嵒 & & & $\overrightarrow{\stackrel{\sim}{*}}$ & $\underset{m}{n}$ & $\stackrel{9}{+}$ & $\begin{array}{l}\infty \\
\dot{m} \\
\dot{m}\end{array}$ & $\underset{\mathfrak{H}}{\stackrel{4}{4}}$ & $\begin{array}{l}n \\
\infty \\
+\infty\end{array}$ & $\underset{m}{\stackrel{N}{n}}$ & & $\stackrel{\pi}{a}$ \\
\hline & \multirow{2}{*}{$\stackrel{n}{\circ}$} & $\stackrel{\widetilde{\pi}}{0}$ & & & $\begin{array}{l}2 \\
\infty \\
1 \\
-1\end{array}$ & $\begin{array}{l}\text { fn } \\
\text { O } \\
\text { ¿ }\end{array}$ & $\begin{array}{l}\stackrel{+}{m} \\
\stackrel{+}{s} \\
\stackrel{-}{-}\end{array}$ & 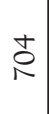 & $\begin{array}{l}\hat{a} \\
\text { aे } \\
\text { ì }\end{array}$ & $\underset{+}{+}$ & \begin{tabular}{l} 
in \\
\multirow{f}{+}{} \\
$\dot{H}$ \\
in
\end{tabular} & & $\begin{array}{l}\infty \\
8 \\
0 \\
0 \\
0 \\
0\end{array}$ \\
\hline & & $\frac{\alpha}{I I}$ & & & $\stackrel{0}{\vec{\lambda}}$ & $\begin{array}{l}n \\
\tilde{n} \\
m\end{array}$ & $\begin{array}{l}0 \\
\dot{f} \\
\dot{f}\end{array}$ & $\begin{array}{c}-1 \\
\infty \\
m\end{array}$ & $\stackrel{m}{\ddot{q}}$ & $\begin{array}{l}0 \\
\dot{b}\end{array}$ & 官 & & $\begin{array}{l}0 \\
\text { in }\end{array}$ \\
\hline & \multirow{2}{*}{$\underset{⿱}{\stackrel{ \pm}{N}}$} & $\stackrel{\widetilde{\pi}}{0}$ & & & $\begin{array}{l}\vec{b} \\
\stackrel{D}{2} \\
\end{array}$ & $\begin{array}{l}\infty \\
\stackrel{+}{+} \\
\stackrel{n}{n} \\
\end{array}$ & 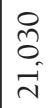 & $\stackrel{8}{\circ}$ & $\begin{array}{l}\text { oे } \\
\text { o } \\
\text { î }\end{array}$ & $\begin{array}{l}0 \\
\hat{\sigma}\end{array}$ & $\begin{array}{l}\text { ஜ } \\
\text { mे } \\
\text { in }\end{array}$ & & $\begin{array}{l}\tilde{a} \\
\text { on } \\
\text { ja }\end{array}$ \\
\hline & & $\frac{\alpha}{I I}$ & & & $\stackrel{+}{\dot{v}}$ & $\begin{array}{l}\dot{0} \\
i n \\
m\end{array}$ & $\begin{array}{l}t \\
\dot{\sigma}\end{array}$ & $\begin{array}{l}\infty \\
\infty \\
m\end{array}$ & $\begin{array}{l}\ddot{q} \\
\dot{y}\end{array}$ & $\stackrel{q}{i q}$ & $\begin{array}{l}\infty \\
\dot{0} \\
m\end{array}$ & & in \\
\hline & \multirow{2}{*}{$\begin{array}{l}m \\
\stackrel{\nu}{2}\end{array}$} & $\begin{array}{l}\vec{\pi} \\
0 \\
\ominus\end{array}$ & & & $\begin{array}{l}\infty \\
\infty \\
\infty \\
\\
\sim\end{array}$ & $\begin{array}{l}\Delta \\
\infty \\
10 \\
-1\end{array}$ & $\begin{array}{l}\text { P } \\
\stackrel{1}{1} \\
\tilde{\lambda}\end{array}$ & $\stackrel{\beth}{\beth}$ & $\begin{array}{l}\hat{\sigma} \\
\sigma \\
-i\end{array}$ & ๙ૂ & 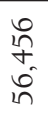 & & $\begin{array}{l}+ \\
\infty \\
\infty \\
\text { ¿ }\end{array}$ \\
\hline & & $\frac{\alpha}{\underline{I}}$ & & & $\stackrel{-}{\vec{\lambda}}$ & $\begin{array}{l}0 \\
i n\end{array}$ & $\begin{array}{l}0 \\
i f \\
f\end{array}$ & $\stackrel{\sim}{\vec{q}}$ & $\stackrel{n}{\tilde{q}}$ & $\stackrel{\sim}{\stackrel{f}{*}}$ & $\begin{array}{l}n \\
\ddot{n}\end{array}$ & & in \\
\hline & \multirow{2}{*}{ 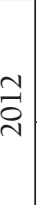 } & 胥 & & & $\begin{array}{l}\vec{\sim} \\
\tilde{n} \\
\pm \\
\pm\end{array}$ & $\begin{array}{l}0 \\
\stackrel{+}{0} \\
\stackrel{0}{-1}\end{array}$ & 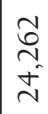 & $\stackrel{m}{ }$ & $\begin{array}{l}0 \\
= \\
=\end{array}$ & 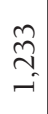 & $\begin{array}{l}\infty \\
\text { o } \\
\text { ñ } \\
\text { in }\end{array}$ & & 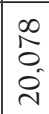 \\
\hline & & $\underset{I I}{q 1}$ & & & $\begin{array}{l}\stackrel{0}{0} \\
\grave{\lambda}\end{array}$ & 官 & in & $\begin{array}{c}0 \\
\dot{n} \\
\end{array}$ & $\stackrel{m}{\tilde{q}}$ & $\stackrel{\sim}{\dddot{q}}$ & $\vec{b}$ & & $\begin{array}{l}\infty \\
\stackrel{\infty}{\circ}\end{array}$ \\
\hline & \multirow{2}{*}{$\vec{\nabla}$} & $\stackrel{\vec{\pi}}{0}$ & & & $\underset{\mathfrak{\sim}}{\stackrel{\sim}{\sim}}$ & 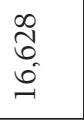 & $\begin{array}{l}\stackrel{2}{\infty} \\
\stackrel{2}{+} \\
\stackrel{+}{\sim}\end{array}$ & 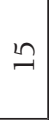 & 㽦 & $\stackrel{m}{\vec{F}}$ & $\begin{array}{l}\hat{n} \\
0 \\
\infty \\
i n\end{array}$ & & $\begin{array}{l}8 \\
\stackrel{0}{m} \\
\infty \\
\infty\end{array}$ \\
\hline & & $\frac{q}{I I}$ & & & $\stackrel{i}{0}$ & $\begin{array}{l}0 \\
\dot{m}\end{array}$ & $\stackrel{n}{q}$ & $\stackrel{m}{m}$ & $\begin{array}{l}0 \\
\dot{q}\end{array}$ & $\underset{\mathfrak{H}}{\stackrel{\sim}{f}}$ & $\stackrel{i}{n}$ & & $\begin{array}{l}\text { in } \\
\text { in }\end{array}$ \\
\hline & \multirow{2}{*}{$\begin{array}{l}\stackrel{0}{\circ} \\
\stackrel{i}{N}\end{array}$} & $\begin{array}{l}\vec{\pi} \\
0 \\
\ominus\end{array}$ & & & $\begin{array}{l}2 \\
\infty \\
\infty \\
n \\
n\end{array}$ & \begin{tabular}{l}
$\infty$ \\
\multirow{2}{\alpha}{} \\
$\underline{0}$
\end{tabular} & 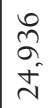 & $a$ & $n$ & $\begin{array}{l}\stackrel{0}{J} \\
\underset{-}{-}\end{array}$ & $\begin{array}{l}+\infty \\
\infty \\
\infty \\
\infty \\
i n\end{array}$ & & 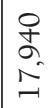 \\
\hline & & $\frac{\alpha}{I I}$ & & & $\vec{i}$ & $\stackrel{m}{m}$ & $\stackrel{m}{i n}$ & $\stackrel{m}{m}$ & Oे & $\stackrel{?}{\circ}$ & $\stackrel{\sim}{n}$ & & $\begin{array}{l}0 \\
\text { in }\end{array}$ \\
\hline 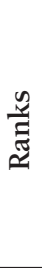 & & & 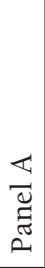 & 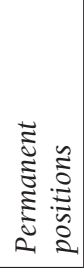 & 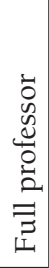 & 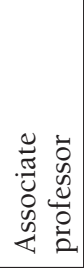 & 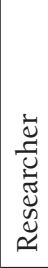 & 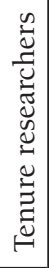 & 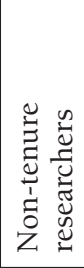 & 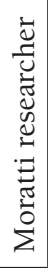 & $\stackrel{\widetilde{\sigma}}{\varrho}$ & $\frac{ص}{\stackrel{\oplus}{\tilde{\Xi}}}$ & 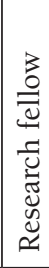 \\
\hline
\end{tabular}


this type of contract (that was the only available till 2011) is likely to have «moved up» the career ladder, «empting» this university rank and leaving their female colleagues trapped in a position that offers no career prospects.

We can fully describe the size of the female disadvantage when comparing these data to the percentage of young female research fellows. As Table 4 shows, the feminization rate of this rank has been constant over time and in 2015 is $50.6 \%$. This clearly shows that a minority of young female academics is successful in obtaining a post as temporary researcher and, in particular, as tenure track researcher.

\section{CONCLUSIONS}

In the last ten years, the Parliament has introduced a number of university reforms that have radically transformed the characteristics of Italian academia. In particular, the so-called Riforma Moratti and Riforma Gelmini have changed the characteristics of the university researcher, the lower rank of the academic career, abolishing the rank of permanent researcher and replacing it with different types of temporary researchers (i., e., tenure and non-tenure researchers). Although academia, as mentioned in the introduction, should be the «land of meritocracy», previous research has shown that the numerous reforms of the Italian universities, being gender neutral, end up favouring men's career progressions. Against this background, the aim of this work is to assess the impact of these changes on men and women's career opportunities, focusing, in particular, on young academics.

In the first part of the paper we described the characteristics, in terms of stability of the post and career opportunities, of the different types of university researchers. The Italian university system is currently constituted of two groups of researchers, those who hold permanent positions (i. e., researchers hired before the two reforms were enacted) and those with temporary contracts (i. e. tenure and non-tenure researchers, recruited after the reforms). Although the Gelmini reform did also introduce important changes in the recruitment processes of full and associate professors, these continue to hold permanent positions.

In the second part of the paper, we analysed the condition of women within the Italian university. Using data on the whole academic staff, we have documented the high level of vertical segregation that still persists in Italian universities. For example, in 2016, women constitute $22.1 \%$ of full professors. Surprisingly, when focusing on researchers who hold temporary contracts, we found a similar pattern; although there are no differences in the gender composition of research fellows, in 2016 female academics are $39.8 \%$ and $42.2 \%$ of tenure and non-tenure track researchers, respectively. 
Our analysis has also thrown light on another aspect of gender inequalities, the concentration of female and male scholars within different disciplines, documenting the high level of horizontal segregation of Italian academia that also distinguishes the presence of young female researchers within the university. For example, women are $19.6 \%$ of tenure researchers in physics compared to $58.9 \%$ in the humanities. We have also shown that there are strong gender differences in the career opportunities of young academics who work in different disciplinary fields. In particular, there are no gender inequalities in disciplines with low female presence, such as physics or industrial engineering and information and communication technology, whereas we find strong differences in academic fields with high feminization rates. For example, in political and social sciences there is a difference of 20 percent points between the percentage of men and women who hold tenure and non-tenure research posts. The situation that we have documented in our paper is similar to the one of other European countries, as described in the EU publications She Figures.

In the last part of this work, we have shown that despite the changes that occurred between 2010 and 2016, women's condition within the Italian university has not undergone major changes. For example, male academics benefitted more than their female colleagues did from the special recruitment plan of the associate professors financed by the MIUR. The female disadvantage is particularly striking for the younger cohort of academics; although $50 \%$ of the research fellows are women, about $40 \%$ of them are employed as tenure researchers.

Taken together, these data suggests that Italian academia is far from being a «land of equal opportunities» for men and women, and, in particular, for the generation of young female researchers. Although the MIUR databases are a unique research resource, they have limitations, as they do not provide information on other aspects that need to be taken into consideration to fully disentangle the mechanisms that are driving the differences in male and female scholars' career progressions. For example, they do not collect information on academics' productivity (e. g., number of publications) or on caring responsibilities (e. g., number of children). Therefore, little is known on the factors behind the high levels of vertical and horizontal segregation that still persist in the Italian academia.

One could speculate that women did not «make it to the top» because of a delayed entry into the university career. In other words, there are fewer women than men in the full-professor rank because fewer women graduated 40 years ago. Although this may be true for the older generation of women, this does not hold true for the younger cohort of female graduates; in some 
disciplines, women are the majority of graduates as well as the majority of researcher fellows. Drawing on economic theories, one may state that women choose not to make an academic career, because of the commitment (in terms of time and energies) it involves and the difficulties in balancing career and family. We do not have any data to test this hypothesis; however, for some disciplines, we found no differences in the percentage of female tenure and non-tenure researchers (see Table 3). This would suggest that, at least in some cases, this hypothesis does not find empirical support. Unless we believe that young female academics' aspirations and work commitment vary by disciplinary field and that, in some cases, women may deliberately choose to apply for precarious positions rather than for more permanent ones (which is somewhat irrational), the economic theories can hardly explain the differences in men and women's career paths.

It is therefore quite likely that the factors that are driving these differences lie elsewhere and lie, in particular, within the university itself and, more specifically, in the formal and informal rules that govern the academics' selection and career advancement processes. In a legislative context characterized by gender-neutral norms (as documented in Section 3), informal mechanisms that are not based on meritocratic criteria end up favouring men's careers. The reforms that the MIUR enacted, ignoring the gender dimension, reinforced these mechanisms and contributed to the reproduction of the female disadvantage within Italian academia. These reforms will have unexpected and possibly unwanted long-term effects for many young female researchers.

\section{REFERENCES}

Bagues, Manuel F, Mauro Sylos Labini and Natalia Zinovyeva. «Le quote rosa non superano l'abilitazione», Lavoce.Info, 24-06-2014. Available at: http://www. lavoce.info/archives/20626/quote-rosa-non-superano-labilitazione, consulted on 20-12-2016.

Baccini, Alberto. «Le donne sono state discriminate dall'abilitazione scientifica nazionale?», Roars, 28-10-2014. Available at: http://www.roars.it/online/ le-donnesono-state-discriminate-nellabilitazione-scientifica-nazionale/, consulted on 20-12-2016.

Bianco, Maria Luisa. Donne al lavoro: cinque itinerari fra le diseguaglianze di genere, Torino: Scriptorium, 1997.

Bianco, Maria Luisa. "Effetti della riforma dei concorsi universitari su carriere accademiche e dinamiche di genere», Polis 16.3 (2002): 417-441. 
Carabelli, Anna Maria, Daniela Parisi and Annalisa Rosselli (a cura di). Che genere di economista? La professione di economista nell'università italiana, Bologna: il Mulino, 1999.

Corsi, Marcella. «Soci SIE: uno sguardo di genere», Commissione di genere, Società Italiana degli Economisti, 2014. Available at: http://www.ingenere.it/ricerche/ soci-sie-uno-sguardo-di-genere, consulted on 20-12-2016.

Corsi, Marcella. «Soci SIE: uno sguardo di genere», Commissione di genere, Società Italiana degli Economisti, 2016. Available at: http://www.siecon.org/online/ wpcontent/uploads/2014/10/SIE_-report-di-genere_151014_MC.pdf, consulted on 20-12-2016.

David, Patrizia. «La scienza al femminile» in Patrizia David and Giovanna Vicarelli (a cura di). Donne nelle professioni degli uomini, Milano: Angeli, 1994: 267-301.

De Paola, Maria, Michela Ponzo and Vincenzo Scoppa. «Donne sull'orlo di una crisi di competizione», Lavoce.Info, 29-07-2014a. Available at: http://www. lavoce.info/archives/29143/donne-competizione-universita/, consulted on 20-12-2016.

De Paola, Maria, Michela Ponzo and Vincenzo Scoppa. «La parità di genere non sale in cattedra», Lavoce.Info, 11-03-2014b. Available at: http://www.lavoce. info/archives/18070/profilo-nuovi-professori-concorso-gelmini/, consulted on 20-12-2016.

De Paola, Maria, Michela Ponzo and Vincenzo Scoppa. «Chi sale in cattedra», Lavoce.Info, 16-06-2015. Available at: http://www.lavoce.info/archives/35703/ la-parita-di-genere-non-sale-in-cattedra/, consulted on 20-12-2016.

EC (European Commission). She Figures 2013. Statistics and Indicators on Gender Equality in Science, Luxemburg: Publication Office of The European Union, 2014. Available at: http://ec.europa.eu/research/swafs/pdf/pub_gender_equality/she_figures_2015-final.pdf, consulted on 20-12-2016.

Facchini, Carla and Nora Schmitz. «Il ruolo della famiglia nella carriera di uomini e donne» in Roberto Moscati (a cura di). Chi governa l'università? Il mondo accademico tra conservazione e mutamento, Napoli: Liguori editore, 1997.

Frattini, Romana and Paolo Rossi. «Report sulle donne nell'università italiana», Meno di zero, 8-9, 2012.

ISTAT. Donne all'università, Bologna: il Mulino, 2001.

Pavolini, Emmanuele and Gianfranco Viesti. «Università: ricercatori in bilico», Lavoce.Info, 15-04-2016. Available at: http://www.lavoce.info/archives/40642/ sempre-meno-docenti-alluniversita/, consulted on 20-12-2016.

ROARS Editorial Board. «I 'ricercatori Moratti' non possono essere esclusi dai concorsi per RTD B», Roars, 09-09-2016. Available at: http://www.roars.it/ online/i-ricercatori-moratti-non-possono-essere-esclusi-dai-concorsi-perrtd-b/, consulted on 20-12-2016. 
Rosselli, Annalisa. «Introduzione», in Anna Carabelli, Daniela. Parisi and Annalisa Rosselli (eds.). Che genere di economista, Bologna: il Mulino, 1999: 7-21.

Sala, Emanuela and Roberta Bosisio. «The Role of Formal and Informal Rules in Italian Academics' Careers. Are there Equal Opportunities for Men and Women?» in Renata Siemienska and Annette Zimmer (eds.). Gendered Career Trajectories in Academia in Cross National Perspective, Warsaw: Wydawnictwo Naukowe Scholar, 2007: 129-160.

Viesti, Gianfranco. Università in declino. Un'indagine sugli atenei da Nord a Sud. Rapporto Fondazione Res, Roma: Donzelli, 2016. 